\title{
Knowledge, Attitude and Practice of Health Care Providers with Regard to Hepatitis-B Infection in Bisha Province, Saudi Arabia
}

\author{
Mohammed Ayed Mubarak Alamri¹, Navin Anand Ingle², Mohammad Abdul Baseer ${ }^{3}$ \\ 1,2,3 Department of Dental Public Health, College of Dentistry, Riyadh Elm University, Riyadh, Saudi Arabia.
}

\section{ABSTRACT}

\section{BACKGROUND}

Health care providers are at greater risk of Hepatitis B infection as they are exposed to blood and biomedical waste products making them vulnerable to be infected when compared to the general population. A thorough understanding and awareness is essential in order to protect themselves and the patient community from this deadly disease.

\section{METHODS}

A total of 231 respondents completed the cross sectional study. A 21 variable questionnaire was employed to assess knowledge, attitude and practice regarding Hepatitis B amongst health care workers after obtaining consent and institutional permission. Data was analysed using SPSS 20.0 version.

\section{RESULTS}

A response rate of $93.6 \%$ resulted in 231 questionnaires to be analysed. The study results suggest that $92.6 \%$ of the respondents expressed concerns regarding HBV (Hepatitis B Virus). $88.7 \%$ of them were vaccinated for the viral infection.

\section{CONCLUSIONS}

A deficiency in awareness was noted regarding attitude and practice concerns of health care workers towards HBV, though awareness was adequate. Regular training programmes are suggested for committed combating of the infection.

\section{KEY WORDS}

Attitude, Hepatitis B, Health Care Providers, Knowledge
Corresponding Author:

Dr. Mohammad Ayed Mubarak Alamri,

Post Graduate Student, Dental Public

Health, College of Dentistry, Riyadh Elm

University, Riyadh, Saudi Arabia.

E-mail:

mohammed.a.alamri@student.riyadh.edu.sa

DOI: $10.14260 /$ jemds $/ 2020 / 800$

How to Cite This Article:

Alamri MAM, Ingle NA, Baseer MA, Knowledge, attitude and practice of health care providers with regard to hepatitis- $B$ infection in Bisha Province, Saudi Arabia.J Evolution Med Dent Sci 2020;9(48):36433647, DOI: 10.14260/jemds/2020/800

Submission 24-06-2020,

Peer Review 14-10-2020,

Acceptance 21-10-2020,

Published 30-11-2020.

Copyright (C) 2020 Mohammad Ayed Mubarak Alamri et al. This is an open access article distributed under Creative Commons Attribution License [Attribution 4.0 International (CC BY 4.0)] 


\section{BACKGROUND}

Hepatitis B virus (HBV) infection accounts to a greater frequency of liver infections, and is the $10^{\text {th }}$ leading cause of public health concern, worldwide. ${ }^{1}$ Globally the statistics of people suffering with acute infectious stage of HBV is two billion and over 350 million are carriers of chronic HBV infection. ${ }^{2}$ The mortality rate of this infection is about one million every year due its complications such as cirrhosis, primary hepatocellular carcinoma and liver cancer. ${ }^{3}$ In India alone, about 100,000 people die every year due to this infection and around 40 million are in carrier stage. ${ }^{4}$

Health care provider (HCP) are at greater risk of contracting the infection owing to the occupational exposure to blood borne pathogens and for the fact that the virus gets transmitted through blood and secretory fluids, which could be easily diagnosed in both acute and chronic stages. ${ }^{5,6}$

It is alarming to note that the incidence of HBV infection is estimated at 3.5 to 4.6 incidence for every $1000 \mathrm{HCP}$, which is clearly higher than the normal population. ${ }^{7}$ Literature evidence also demonstrates that HBV infection contraction by HCP is four times greater than the general population. ${ }^{8}$ Also, the greater prevalence of $\mathrm{HBV}$ in the normal populations puts the HCP at greater risk. The study of Alrowaily MA et al, ${ }^{9}$ has reported a greater prevalence of HBV in the country men of Saudi Arabia. It is hence imperative for the HCP to be aware of this occupational risk. In this background, the study was conducted to evaluate knowledge, attitude and practice regarding HBV in health care provider of Bisha Province, Saudi Arabia.

\section{METHODS}

A descriptive study was conducted in Bisha province to assess the knowledge, attitude and practice of health care personnel towards Hepatitis B infection, from March 2020 to April 2020. The study protocol was approved from the Institutional Review board of Riyadh Elm University (FPGRP / 2020 / 453 / 107 / 101). A total of 231 HCP comprising of dentists, physicians, nurses, dental auxiliaries, physiotherapist and $\mathrm{x}$ ray technicians formed the study sample. Informed consent of all participants was obtained after clearly explaining the purpose of the study.

Based on the assumption of $80 \%$ prevalence of correct knowledge regarding HBV in HCP, the sample size was obtained at 246, at a confidence interval of $95 \%$ and $5 \%$ margin of error. (Based on single population proportion). Total enumeration sampling technique of all health care providers of Riyadh Elm University in Bisha Province were taken as the sample for the present study.

A pre-designed, self-administered questionnaire was used to elicit the information which was adapted as per the study of Yu Ling Quinet al. ${ }^{10}$ The variables elaborated demographic characteristics, knowledge regarding HBV route of transmission, vaccination history, appropriate preventive measures on accidental exposure and clinical outcome. Practice related questions detailed on use of standard or universal precautions during treatment and vaccination a total of 21 multiple choice questions were used. Only completed questionnaire was retained.
The questionnaire was pilot tested on a group of 20 HCPs prior to the start of the study in order to ensure for the content clarity and relevance. No modifications were made in the questionnaire after evaluating. The respondents in the pilot study were not included for the final analysis. The questionnaire was distributed using Google forms. Confidentiality of all participants was ensured.

\section{Statistical Analysis}

Data collected was transferred to spreadsheets and analysed using SPSS Ver. 20.0. Frequencies and percentages for each variable were calculated. Comparison analysis between respondents based on their job title was done by employing Chi square test, setting a level of significance at $5 \%$.

\section{RESULTS}

Out of the 240 questionnaires distributed, 231 respondents completed the form which was subsequently analysed resulting in a response rate of $93.9 \%$. The general characteristic of the health care personnel is presented in Table 1. Majority of the study population were between the ages of $30-40$ years ( $55 \%$ ), followed by $<30$ years $(31.6 \%)$ and $41-50$ years $(11.3 \%) .64 .9 \%$ of the recruited population were males and $35.1 \%$ females.

\begin{tabular}{|c|c|c|}
\hline \multirow[t]{2}{*}{ Characteristics } & \multicolumn{2}{|c|}{ Health Care Personnel } \\
\hline & Number & $\%$ \\
\hline \multicolumn{3}{|c|}{ Age (years) } \\
\hline$<30$ years & 73 & 31.6 \\
\hline $30-40$ & 127 & 55.0 \\
\hline $41-50$ & 26 & 11.3 \\
\hline $51-60$ & 4 & 1.7 \\
\hline$>60$ & 1 & 0.4 \\
\hline \multicolumn{3}{|c|}{ Gender } \\
\hline Male & 150 & 64.9 \\
\hline Female & 81 & 35.1 \\
\hline \multicolumn{3}{|c|}{ Job Title } \\
\hline Dentist & 44 & 19.0 \\
\hline Physician & 57 & 24.7 \\
\hline Pharmacist & 11 & 4.8 \\
\hline Nurse & 108 & 46.8 \\
\hline Physiotherapist & 1 & 0.4 \\
\hline Dental Auxiliary & 8 & 3.5 \\
\hline $\mathrm{X}$ ray Technician & 2 & 0.9 \\
\hline \multicolumn{3}{|c|}{ Qualification } \\
\hline Bachelor & 184 & 79.7 \\
\hline Master Degree & 10 & 4.3 \\
\hline Diploma & 31 & 13.4 \\
\hline PHD & 1 & 0.4 \\
\hline Board & 3 & 1.3 \\
\hline Intermediary & 2 & 0.9 \\
\hline \multicolumn{3}{|c|}{ Work Experience } \\
\hline$<5$ & 66 & 28.6 \\
\hline $5-10$ & 98 & 42.4 \\
\hline $10-20$ & 50 & 21.6 \\
\hline $20-30$ & 16 & 6.9 \\
\hline$>30$ & 1 & 0.4 \\
\hline \multicolumn{3}{|c|}{ Employer } \\
\hline Public & 214 & 92.6 \\
\hline Private & 17 & 7.4 \\
\hline \multicolumn{3}{|c|}{ Nationality } \\
\hline Saudi & 184 & 79.7 \\
\hline Non-Saudi & 46 & 19.9 \\
\hline \multicolumn{3}{|c|}{$\begin{array}{c}\text { Table 1. Distribution of Health Care Personnel } \\
\text { According to Their General Characteristics }\end{array}$} \\
\hline
\end{tabular}




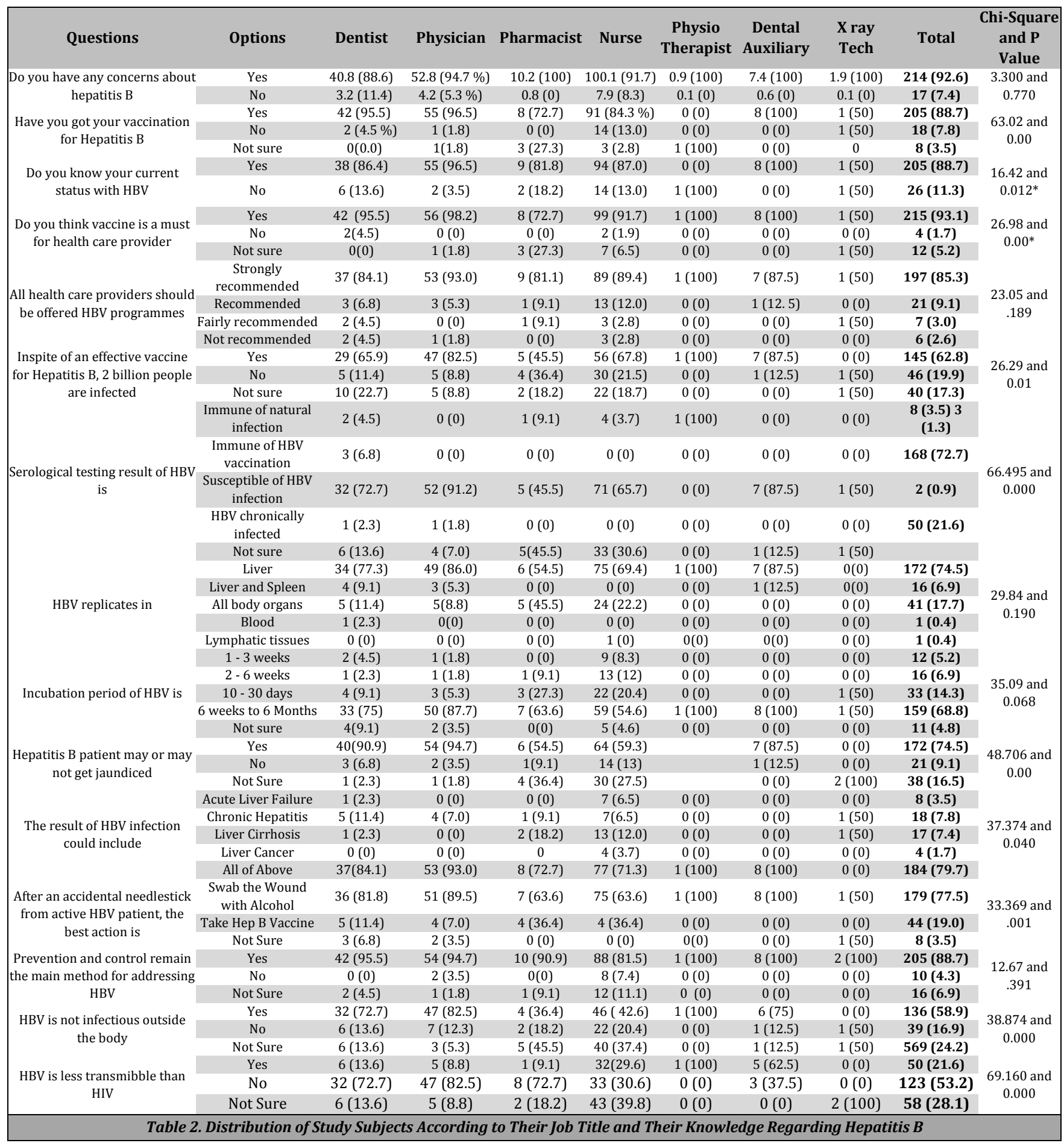

As the study aimed to evaluate the variables in health care personnel, a wide array of health service men was included, with dentists forming $19 \%$, physicians accounting to $24.7 \%$ and nurses to $46.8 \%$. Most of the health care personnel had a bachelor's degree $(79.7 \%)$. Nearly half of the professionals $(42.4 \%)$ had an experience of 5 to 10 years and $92.6 \%$ worked in the public sector. (Table 1).

On comparing knowledge related responses between HCPs, it was seen that majority of dentists (88.6\%) and physicians (94.7\%) did not have any concerns regarding Hepatitis B. A significant difference was observed between the health care personnel for knowing the current HBV status, wherein $\mathrm{X}$ ray technicians and physiotherapists were not well aware for the mandation of hepatitis B vaccine. A good percentage of health care personnel were unaware of the number of people affected, with only $65.9 \%$ of dentists, 45.5 $\%$ of pharmacists, $67.8 \%$ of nurses and $0 \% \mathrm{x}$-ray technicians knowing the right answer. A good majority of study population reported it was better to wash an accidental needle prick with alcohol and soap than getting vaccinated. (Table 2)

The comparative analysis on practice related responses yielded that $64 \%$ and $19.5 \%$ of the respondents used double gloves always and often. Only $1.7 \%$ never used double gloves while performing a surgical procedure. It was disheartening to find that only around $30 \%$ of the health care personnel wore glasses for protection. A good majority of them wore masks during surgical procedure (14.7\% often and $82.7 \%$ always) (Table 3) 


\begin{tabular}{|c|c|c|c|c|c|c|c|c|c|c|}
\hline Questions & Options & Dentist & Physician & Pharmacist & Nurse & Physiotherapist & $\begin{array}{l}\text { Dental } \\
\text { Auxiliary }\end{array}$ & $\begin{array}{c}\text { X-Ray } \\
\text { Tech }\end{array}$ & Total & $\begin{array}{c}\text { Chi-Square } \\
\text { and (P Value) }\end{array}$ \\
\hline \multirow{4}{*}{$\begin{array}{c}\text { Have You Ever Used Double } \\
\text { Gloves during Surgical } \\
\text { Procedure }\end{array}$} & Often & $4(9.1)$ & $10(17.5)$ & $1(9.1)$ & 29 (26.9) & $0(0)$ & $0(0)$ & $1(50)$ & 45 (19.5\%) & \multirow{4}{*}{$64.585 \& 0.00$} \\
\hline & Never & $0(0)$ & $1(1.5)$ & $2(18.2)$ & $1(0.9)$ & $0(0)$ & $0(0)$ & $0(0)$ & $4(1.4)$ & \\
\hline & Always & $33(75)$ & $40(70.2)$ & $1(9.1)$ & $68(63.0)$ & $0(0)$ & $7(87.5)$ & $0(0)$ & $149(64.5)$ & \\
\hline & Sometimes & $7(15.9)$ & $6(10.5)$ & $7(63.6)$ & $10(9.3)$ & $1(100)$ & $1(12.5)$ & $1(50)$ & $33(14.3)$ & \\
\hline \multirow{4}{*}{$\begin{array}{l}\text { Have You Used Glasses } \\
\text { during Surgical } \\
\text { Procedure }\end{array}$} & Often & $11(25)$ & $2(3.5)$ & $0(0)$ & $1(0.9)$ & $0(0)$ & $0(0)$ & $0(0)$ & $14(6.1)$ & \multirow{4}{*}{$130.973 \& 0.00$} \\
\hline & Never & $0(0)$ & $9(15.8)$ & $6(55.5)$ & $66(61.1)$ & $0(0)$ & $0(0)$ & $2(100)$ & 83 (35.9) & \\
\hline & Always & $24(54.4)$ & $12(21.1)$ & $0(0)$ & $13(12.0)$ & $0(0)$ & $5(62.5)$ & $0(0)$ & $54(23.4)$ & \\
\hline & Sometimes & $9(20.5)$ & $34(59.6)$ & $5(45.5)$ & $28(25.9)$ & $1(100)$ & $3(37.5)$ & $0(0)$ & $80(34.6)$ & \\
\hline \multirow{3}{*}{$\begin{array}{l}\text { Have You Used Mask during } \\
\text { Surgical Procedure }\end{array}$} & Often & $0(0)$ & $6(10.5)$ & $2(18.2)$ & $24(22.2)$ & $0(0)$ & $0(0)$ & $2(100)$ & $34(14.7)$ & \multirow{3}{*}{$111.634 \& 0.000$} \\
\hline & Always & $44(100)$ & $51(89.5)$ & $4(36.4)$ & $83(76.9)$ & $1(100)$ & $8(100)$ & $0(0)$ & $191(82.7)$ & \\
\hline & Sometimes & $0(0)$ & $0(0)$ & $5(45.5)$ & $1(0.9)$ & $0(0)$ & $0(0)$ & $0(0)$ & $6(2.6)$ & \\
\hline
\end{tabular}

\begin{tabular}{|c|c|c|c|c|c|c|c|c|c|c|}
\hline Questions & Options & Dentist & Physician & Pharmacist & Nurse & Physiotherapist & $\begin{array}{c}\text { Dental } \\
\text { Auxiliary }\end{array}$ & $\begin{array}{c}\text { X-Ray } \\
\text { tech }\end{array}$ & Total & $\begin{array}{c}\text { Chi Square and } \\
\text { (P Value) }\end{array}$ \\
\hline Do You Recommend & Yes & $42(95.5)$ & $56(98.2)$ & $10(90.9)$ & $104(96.3)$ & $1(100)$ & $8(100)$ & $2(100)$ & $223(96.5)$ & \multirow{3}{*}{$8.646 \& 0.733$} \\
\hline Mandatory HBV Vaccine in all & No & $2(4.5)$ & $0(0)$ & $0(0)$ & $1(0.9)$ & $0(0)$ & $0(0)$ & $0(0)$ & $3(1.3)$ & \\
\hline $\begin{array}{l}\text { Health Care Workers of Saudi } \\
\text { Arabia }\end{array}$ & Not Sure & $0(0)$ & $1(1.8)$ & $1(9.1)$ & $3(2.8)$ & $0(0)$ & $0(0)$ & $0(0)$ & $5(2.2)$ & \\
\hline Do You Feel Comfortable & Yes & $22(50$ & $40(70.2)$ & $4(36.4)$ & $60(55.6)$ & $0(0)$ & $3(37.5)$ & $1(50)$ & $130(56.3)$ & \multirow{3}{*}{$6.322 \& 0.453$} \\
\hline Treating HBV Infected & No & $21(47.7)$ & $14(24.6)$ & $3(27.3)$ & $17(15.7)$ & $1(100)$ & $3(37.5)$ & $0(0)$ & $59(25.5)$ & \\
\hline Patients & Not Sure & $1(2.3)$ & $3(5.3)$ & $4(36.4)$ & $3(28.7)$ & $0(0)$ & $2(25.0)$ & $1(50)$ & $42(12.2)$ & \\
\hline Do You Accept a Colleague & Yes & $14(31.8)$ & $35(61.4)$ & $1(9.1)$ & $52(48.1)$ & $0(0)$ & $0(0)$ & $0(0)$ & $102(44.2)$ & \multirow{3}{*}{$34.512 \& .001$} \\
\hline With HBV in the Same Work & No & $24(54.5)$ & $15(26.3)$ & $6(54.3)$ & $33(30.6)$ & $0(0)$ & $5(62.5)$ & $2(100)$ & $85(36.8)$ & \\
\hline Place & Not Sure & $6(13.6)$ & $7(12.3)$ & $4(36.4)$ & $23(21.3)$ & $1(100)$ & $3(37.5)$ & $0(0)$ & $44(1.9)$ & \\
\hline
\end{tabular}

A comparative analysis on attitude related responses showed that $96.5 \%$ of the health care personnel of all cadre recommended HBV vaccine mandatorily in Saudi Arabia workers. Only about $56.3 \%$ of the workers felt comfortable in treating HBV patients and $44.2 \%$ felt comfortable working with a colleague affected with HBV in the office. (Table 4).

Regarding participant's response for transmission of HBV through various modes. $42 \%$ of the total participants felt HBV can be transmitted by sharing toilet, which was significant. $16.9 \%$ of the respondents felt HBV can spread by hugging and $87.9 \%$ did not feel that it could be transmissible through sneezing and coughing. Only $30.3 \%$ of the total participants knew that it can spread by needle prick and $96.1 \%$ felt it could be transmissible through sexual intercourse.

\section{DISCUSSION}

The current study was done to assess the awareness of health care personnel regarding HBV-transmission and prevention in Bisha Province as HCP are at a greater risk of contracting hepatitis infection.

Health care personnel of all sects are at greater risk of HBV exposure and infection due to usage of extensive use of sharp instruments contaminated with infected body fluids such as blood and saliva which forms the main mode of HBV transmission. Dentists in particular are at three to four fold times and surgical specialists about 6 times at greater risk than the general population. Vaccination and use of personnel protective equipment can control this disease to a major extent. HBV vaccine is recommended for all health care workers since its availability in 1982 due to their exposure to contaminated blood and body fluids. ${ }^{11}$

It was encouraging to know that 205 (88.5\%) of the study respondents were vaccinated for HBV infection, which was in concordance with Patil et al ${ }^{12}$ reporting $96.2 \%$ of their participants being vaccinated. But, contradictory to the study findings of Singhal et al ${ }^{13}$ which reported only $41.9 \%$ of their HCP to be vaccinated. At this point, it is necessary to understand that not all people who are vaccinated are immune to the disease. In the study done by Al Hazmi Ahmad Homoud et al, ${ }^{14}$ only $70 \%$ of their vaccinated HCWs were immune. This could be explained by factors such as not everybody responds to the vaccine, incomplete vaccination dose and decline in anti-HBs titers due to passage of time. 15,16

Complying with the standard precautions is a key factor in ensuring safety against HBV infection. The study results showed that a majority of respondents used gloves and mouth masks while attending patients with only $14.3 \%$ and $2.6 \%$ of them using it sometimes respectively and only $1.7 \%$ of them never used gloves during any procedures. But, the figures for the usage of protective glasses were not promising with 35.9 $\%$ never using them at all. Compared to the study of AlHazmi Ahmad Homoud,14 which reported only $28.3 \%$ wearing eyeglasses and $38.3 \%$ wearing facemasks, the current study results were more promising.

In order to optimize safety measurements, it is important that physicians must be aware of the various modes of HBV transmission. The present study findings demonstrated an appreciable degree of knowledge regarding transmission among respondents, which was similar to Al Hazmi Ahmad homoud. 13

$96.5 \%$ of the respondents opined that vaccination against HBV is mandatory for all Saudi Arabia HCP and for regular training programs reflecting a positive attitude. This was similar to the study of Dieriri $\mathrm{K}$ et $\mathrm{al}^{17}$, which also showed positive enthusiasm in Moroccan health workers.

Acceptance of a colleague infected with HIV, however presented a dimmed response with only $44.2 \%$ of the HCWs giving 'yes' as a reply. This numbers was slightly lesser to the study of Al Hazmi Ahmad homoud ${ }^{14}$ having $60.8 \%$ acceptance. This demonstrates that misconceptions about the infection must be addressed. A greater emphasis must be placed in the dental teaching curriculum at both undergraduate and post graduate levels for bettering concepts and understanding facts.

The proposal of national policy declaration for protecting dental health care personnel from infections by Tidbewal et al ${ }^{18}$ must be adapted and emphasised for all health care 
workers. This includes availability of vaccination in an aggressive manner coupled with comprehensive health and disability insurance. Such concepts will help beat the prejudices and fear amongst health care personnel bringing a positive attitudinal change towards hepatitis B patients and the infection.

However, generalization of the study results to the entire Bisha province must be exercised with caution owing to its single centre design. Studies with multi centre inclusion and a larger sample size are needed to draw broader conclusions about the disease awareness.

Additionally, biomedical waste management also needs to be considered in prevention of HBV infection. Health care personnel must be adequately trained and periodically evaluated for proper hospital waste disposal. Reinforcing health education and conduction training programs periodically is emphasised. Safety of health care personnel must be aimed at in a comprehensive effort.

\section{CONCLUSIONS}

The present study showed that increasing awareness amongst health care provider of Bisha city is important considering the global menace of Hepatitis B infection. Comprehensively planned policies for HBV infection, diagnosis and vaccination is necessary for all health care personnel.

Data sharing statement provided by the authors is available with the full text of this article at jemds.com.

Financial or other competing interests: None.

Disclosure forms provided by the authors are available with the full text of this article at jemds.com.

\section{REFERENCES}

[1] Samuel So, Aderibigbe SA, Salami TA, et al. Health workers' knowledge, attitude and behaviour towards hepatitis B infection in Southern Nigeria. Int J Med Sci 2009;1(10):418-24.

[2] World Health Organization. Hepatitis B. (Fact Sheet no. 204). Geneva: WHO. http://www.who.int/mediacentre/factsheets/fs204/en/ index.html.

[3] Goebel WM. Reliability of the medical history in identifying patients likely to place dentists at an increased hepatitis risk. J Am Dent Assoc 1979;98(6):907-13.

[4] Taneja N, Biswal M. Rapid Assessment of Hepatitis B Vaccine Introduction in India. Proposal for INS support: India-GAVI Alliance. Aug 1st-6th, 2004. www.gavialliance.org/country/india/documents.
[5] Abedi F, Madani H, Asadi A, et al. Significance of bloodrelated high-risk behaviors and horizontal transmission of hepatitis B virus in Iran. Arch Virol 2011;156(4):62935.

[6] Wilkins T, Zimmerman D, Schade RR. Hepatitis B: diagnosis and treatment. Am Fam Physician 2010;81(8):965-72.

[7] Kesieme EB, Uwakwe K, Irekpita E, et al. Knowledge of hepatitis $B$ vaccine among operating room personnel in Nigeria and their vaccination status. Hepat Res Treat 2011;2011:157089.

[8] Singhal V, Bora D, Singh S. Hepatitis B in health care workers: Indian scenario. J Lab Physicians 2009;1(2):418.

[9] Alrowaily MA, Abolfotouh MA, Ferwanah MS. Hepatitis B virus sero-prevalence among pregnant females in Saudi Arabia. Saudi J Gastroenterol 2008;14(2):70-2.

[10] Qin YL, Li B, Zhou YS, et al. Prevalence and associated knowledge of hepatitis B infection among healthcare workers in Freetown, Sierra Leone. BMC Infectious Dis 2018;18:315.

[11] Polakoff S, Tillett HE. Acute viral hepatitis B: Laboratory reports 1975-9. Br Dent J (Clin Res Ed) 1982;284:188-2.

[12] Patil S, Rao RS, Agarwal A. Awareness and risk perception of hepatitis B infection among auxiliary healthcare workers. J Int Soc Prev Community Dent 2013;3(2):67-71.

[13] Singhal V, Bora D, Singh S. Prevalence of hepatitis B virus infection in healthcare workers of a tertiary care centre in India and their vaccination status. J Vaccines Vaccin 2011;2:2.

[14] Homoud AHA. Knowledge, attitude and practice of primary healthcare physicians concerning the occupational risks of hepatitis B virus in Al Jouf Province, Saudi Arabia. J Infect Public Health 2014;7(4):257-70.

[15] Sukriti, Pati NT, Sethi A, et al. Low levels of awareness, vaccine coverage and the need for boosters among health care workers in tertiary care hospitals in India. J Gastroenterol Hepatol 2008;23(11):1710-5.

[16] Mast EE, Weinbaum CM, Fiore AE, et al. A comprehensive immunization strategy to eliminate transmission of hepatitis B virus infectionin the United States: recommendations of the Advisory Committee on Immunization Practices (ACIP) Part II: immunization of adults. MMWR Recomm Rep 2006;55(RR-16):1-33.

[17] Djeriri K, Laurichesse H, Merle JL, et al. Hepatitis B in Moroccan health care workers. Occup Med (Lond) 2008;58(6):419-24.

[18] Tibdewal H, Barad P, Kumar S. Comparing dental and medical student's knowledge and attitudes toward hepatitis B, C and HIV infected patients in India - a crosssectional study. J Int Oral Health 2009;1(1):20-32. 